\title{
Ocena kompatybilności rop naftowych metodą pompową i filtracyjną
}

\section{Crude oil compatibility testing using pumping and filtration methods}

\author{
Sławomir Szuflita, Wojciech Krasodomski, Jerzy Kuśnierczyk, Mirosław Wojnicki, Marcin Warnecki \\ Instytut Nafty i Gazu - Państwowy Instytut Badawczy
}

\begin{abstract}
STRESZCZENIE: Z danych Narodowego Banku Polskiego wynika, że w 2019 roku import ropy do Polski wyniósł 26,3 mln ton, z czego główny jej wolumen pochodził z Rosji. Konieczność zapewnienia większego bezpieczeństwa energetycznego kraju wymusza dywersyfikację dostaw ropy naftowej, przez co największe krajowe rafinerie z roku na rok zwiększają udział dostaw z różnych źródeł. Pociąga to za sobą potrzebę nieustannego uzyskiwania informacji o opłacalności przerobu nowych rodzajów ropy i potencjalnych problemach skutkujących podwyższeniem kosztów. Kontrole jakości oferowanych na rynku surowców pomagają zminimalizować ryzyko zakupu niekompatybilnych gatunków rop dzięki upewnieniu się, że proponowana partia spełnia właściwe wymagania jakościowe. Szczególne znaczenie ma fakt, że badania takie należy wykonywać wyprzedzająco, zanim zostanie podjęta decyzja o zakupie konkretnego surowca naftowego i wprowadzeniu go do instalacji w rafinerii. Często jednak zdarza się, że szczegółowe badania wykonywane są dopiero po zakupie. Należy zwrócić uwagę, że samo badanie właściwości fizykochemicznych i określanie wydajności poszczególnych frakcji nie jest wystarczające. Wytrącanie osadów w ciągu logistycznym ropy naftowej jest istotnym problemem zarówno w instalacjach rurociągowych, bazach magazynowych, jak też w instalacjach rafineryjnych, w których przerabiana jest ropa zawierająca zdyspergowane osady. We wcześniejszym etapie badań opracowano skuteczną metodę filtrowania pozwalającą na określenie kompatybilności rop i ich mieszanin. Obecnie uwagę skupiono na opracowaniu nowej metody, która pozwoliłaby na szybszą możliwość wykonania pomiaru kompatybilności przy jednoczesnej możliwości ponownego wykorzystania tej samej próbki. Opracowany nowy sposób badań kompatybilności metodą pompową przetestowano na dwóch ropach pochodzących z różnych kierunków dostaw. Pomiary wykonano dla rop i ich mieszanin w temperaturze $150^{\circ} \mathrm{C}$ pod ciśnieniem 25 bar. Pomiar kompatybilności rop metodą filtrowania wykorzystano do celów porównawczych, wyznaczając na podstawie masy osadu odseparowanego na specjalistycznych filtrach dopuszczalne udziały procentowe, w których mieszaniny węglowodorowe były kompatybilne.
\end{abstract}

Słowa kluczowe: asfalteny, parafiny, filtrowanie, kompatybilność rop, dywersyfikacja dostaw ropy.

ABSTRACT: According to the National Bank of Poland, by the end of 2019, oil imports to Poland amounted to 26.3 million tonnes of crude oil, where the main volume came from Russia. The need to ensure greater energy security enforces the diversification of crude oil supplies, thus the largest domestic refineries are increasing the share of supplies from different sources each year. This entails the need for continuous information on the profitability of processing new types of crude oil and potential problems resulting in increased cost. Quality control of the crude oil offered on the market helps minimize the risk of purchasing incompatible oil types by ensuring that the proposed shipment meets the relevant quality requirements. Of particular importance is the fact that such tests should be performed prior to the decision to purchase a particular crude oil and introduce it to the refinery's installation. It often happens, however, that detailed tests are performed only after the purchase. It is important to note that testing the physicochemical properties and determining the yield of individual fractions alone is not sufficient. Precipitation of sediments in the logistic chain of crude oil is a significant problem both in pipeline installations, storage depots, and refinery installations, where crude oil containing dispersed sediments is processed. In the previous stage of work, an effective filtration method was developed to determine the compatibility of crude oils and their mixtures. Now, attention was focused on developing a new method that allowed for a faster compatibility measurement capability along with reusing samples for another measurement. The developed new method of pump compatibility testing was tested for two crude oils from different supply directions. The measurements were performed for crude oils and their mixtures at $150^{\circ} \mathrm{C}$ under 25 bar pressure. Compatibility of crude oils with the filtration method was used for comparison, where based on the mass of sediment separated on special filters, the allowable concentrations where hydrocarbon mixtures were compatible were determined.

Key words: asphaltenes, paraffins, filtration, oil compatibility, supply chain diversification.

Autor do korespondencji: S. Szuflita, e-mail: slawomir.szuflita@inig.pl

Artykuł nadesłano do Redakcji: 20.11.2020 r. Zatwierdzono do druku: 29.06.2021 r. 


\section{Wstęp}

Przetwórstwo ropy naftowej na świecie odbywa się w sposób ciągły i na szeroką skalę. Wraz z rozwojem gospodarczym stale wzrasta popyt na produkty węglowodorowe, dlatego większość rafinerii pracuje z maksymalną mocą produkcyjną. W takiej sytuacji każdorazowy przypadek, w którym zachodzi konieczność wyłączenia z użycia danej jednostki lub przerwy w pracy danej instalacji jest niezwykle kosztowny. Ropy naftowe przetwarzane w rafineriach są złożoną mieszaniną węglowodorów, w której rozpuszczone lub zawieszone są związki heteroorganiczne. Tego rodzaju układy cechuje zwykle pewna niestabilność, związana z możliwością wytrącania się struktur wielofazowych zależnych od charakteru chemicznego składników ropy. Zjawiska te wpływają niekorzystnie na procesy rafineryjne.

Mieszaniny węglowodorów pochodzących z rop naftowych generują powstawanie zawiesin poprzez zmianę charakteru chemicznego środowiska. Zaburzona równowaga prowadzi do powstawania osadów, które mogą blokować infrastrukturę rafinerii - zbiorniki, rurociągi, a także wymienniki ciepła (Krasodomski et al., 2020). Może to spowodować konieczność częstego wyłączania jednostki na czas zaplanowanego bądź - co gorsza - nieplanowanego oczyszczania. Ponadto osady te izolują powierzchnie zaprojektowane do przenoszenia ciepła i skutkują jego stratami, co znacznie podnosi koszty operacyjne. Otwarty rynek i kwestie bezpieczeństwa energetycznego skłaniają koncerny naftowe do pozyskiwania ropy naftowej z różnych źródeł, przez co istnieje silna potrzeba zintensyfikowania prac badawczych nad kompatybilnością różnych typów rop pod kątem wytrącania się osadów.

\section{Analiza teoretyczna}

\section{Fizyczny model ropy naftowej}

Przemiany fazowe ropy naftowej są skomplikowane ze względu na dużą ilość różnorodnych cząsteczek tworzących mieszaninę oraz dlatego, że wykazuje ona właściwości zarówno układu koloidalnego, jak i roztworu (Wiehe i Kennedy, 2000). Ropę, w skład której wchodzi ponad milion różnych cząstek, klasyfikuje się w czterech typach: asfaltenów (A), aromatów (a), węglowodorów nasyconych (s) i żywic (R) (Pfeiffer i Saal, 1940). Na rysunku 1 przedstawiono przybliżony model fizyczny ropy naftowej.

$\mathrm{W}$ ropie naftowej asfalteny pozostają w równowadze fazowej, która może zostać łatwo zaburzona poprzez zwiększenie udziału węglowodorów nasyconych lub zmniejszenie ilości żywic lub aromatów (Wiehe, 2008).
Mieszanie różnych typów ropy naftowej może znacząco zmienić zawartość tych składników w ostatecznej mieszaninie, co doprowadzi do zaburzenia równowagi i wytrącenia asfaltenów.

$$
\begin{gathered}
\text { s s } \\
\text { s a a s } \\
\text { s a R R R a } \\
\text { s a RAR a s } \\
\text { s a R A R a s } \\
\text { s a R R R a } \\
\text { s a a s } \\
\text { s s s }
\end{gathered}
$$

A - asfalteny (substancja rozpuszczona)

$\mathrm{R}$ - żywice (dyspersant)

a - aromaty (rozpuszczalnik)

s - węglowodory nasycone (nierozpuszczalnik)

Rys. 1. Uproszczony model ropy naftowej (Wiehe i Kennedy, 2000)

Fig. 1. Simplified crude oil model (Wiehe and Kennedy, 2000)

\section{Wtaściwości asfaltenów}

Asfalteny są makrocząsteczkami zbudowanymi z aromatycznego „rdzenia” zawierającego heteroatomy (tlenu, azotu lub siarki) i z łańcuchów alifatycznych. Są one zazwyczaj definiowane jako frakcja nierozpuszczalna w węglowodorach nasyconych, np. n-heptanie, natomiast częściowo rozpuszczalna w węglowodorach aromatycznych takich jak np. toluen. Nawet w niewielkich stężeniach cząsteczki asfaltenów mają tendencję do agregowania i flokulacji, będąc źródłem poważnych zagrożeń podczas wydobycia i przetwarzania ropy naftowej (Lubaś et al., 2012).

Przyczyny nierozpuszczalności asfaltenów są następujące (Wiehe, 2008; Painter et al., 2015):

- wiązania wodorowe lub inne interakcje donor-akceptor;

- duża masa cząsteczkowa;

- polarność.

\section{Badania stabilności ropy naftowej}

Poniżej przedstawiono dostępne w literaturze metody laboratoryjne i obliczeniowe do określania stabilności ropy naftowej:

- wskaźnik niestabilności koloidalnej (ang. colloidal instability index, CII) (Wiehe i Kennedy, 2000);

- wskaźnik stabilności koloidalnej (ang. colloidal stability index, CSI) (Goual i Firoozabadi, 2002; Rogel i Carbognani, 2003);

- wskaźnik stabilności (ang. stability index) (Asomaning i Watkinson, 2000);

- wykres Stankiewicza (Stankiewicz et al., 2002); 
- parametr stabilności Sepúlvedy - analiza jakościowoilościowa (ang. qualitative-quantitative analysis, QQA) (Sepúlveda et al., 2010);

- parametr stabilności Sepúlvedy - krzyżowy wykres stabilności (ang. stability cross plot, SCP) (Sepúlveda et al., 2010).

\section{Laboratoryjne badania kompatybilności ropy naftowej:}

- $\quad$ analiza SARA (Wang i Buckley, 2003; ASTM D5186-19).

- określenie początku wytrącania asfaltenów (ang. onset of asphaltene precipitation, OAP) (Warnecki, 2011);

- analiza wartości P (P-value);

- analiza wartości S (S-value);

- aomiar separacji fazowej indukowanej n-heptanem z wykorzystaniem skanera optycznego (Guzmán et al., 2017);

- statyczny test stabilności, w którym najczęściej stosowanym parametrem jest zawartość osadu asfaltenowego (Guzmán et al., 2017);

- test punktowy wykorzystywany do wykrywania ewentualnej niekompatybilności rop naftowych ze względu na różnice w ich charakterze. Jedna kropla każdej mieszaniny jest umieszczana na papierze filtracyjnym. Po wysuszeniu jest ona klasyfikowana wizualnie do danego typu (ASTM D4740-19).

\section{Metodyka badań}

Do badań kompatybilności rop handlowych użyto dwóch różniących się od siebie parametrami rop. Badania polegały na wykonaniu serii pomiarowej z wykorzystaniem metody filtrowania - ich wyniki, jako sprawdzone i potwierdzone doniesieniami przemysłowymi, stanowiły bazę do porównania. Do filtrowania użyto specjalistycznego filtra specjalnie przystosowanego do tego typu badań. Zestaw filtrujący wyposażony został w szklany filtr $0,7 \mu \mathrm{m}$ odporny na wysokie temperatury. Następnie po dokonaniu modyfikacji aparatury wykonano serię pomiarów metodą pompową, a uzyskane wyniki zostały skonfrontowane/porównane z uzyskanymi metodą filtracyjną.

\section{Opis aparatury i dwóch sposobów pomiaru kompatybil- ności rop i ich mieszanin}

Badania kompatybilności różnych rop prowadzono z wykorzystaniem bezrtęciowej aparatury PVT do badań właściwości fazowych płynów złożowych (rys. 2).

Przedstawioną aparaturę wykorzystano do ciśnieniowych badań kompatybilności mieszanin ropnych w różnych temperaturach. Dla realizacji tych badań zestaw PVT został odpowiednio rozbudowany dodatkowo o szereg połączeń wysokociśnieniowych oraz o ultratermostat służący do utrzymania

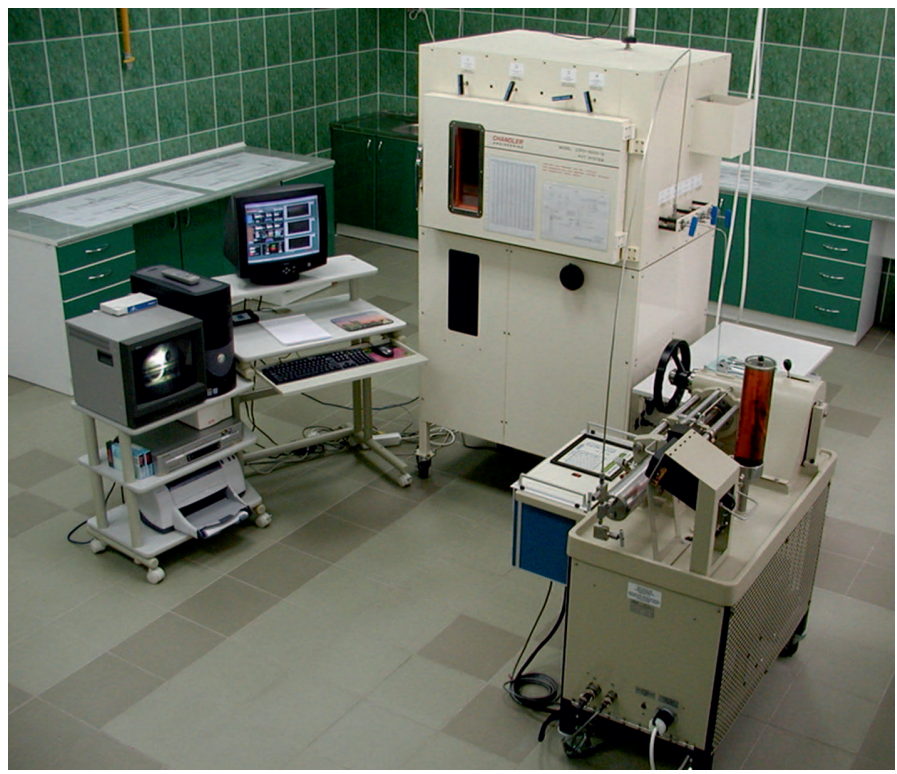

Rys. 2. Aparatura do badań PVT firmy Chandler Engineering Model 2370-3000-G PVT System (Lubaś et al., 2012)

Fig. 2. Chandler Engineering PVT apparatus -2370-3000-G Model (Lubaś et al., 2012)

zadanej temperatury (rys. 3 i 4). Takie podejście umożliwiało ogrzanie przepływającej próbki na odcinku pomiarowym, co jest głównym argumentem wykorzystania ultratermostatu w przeprowadzonych badaniach.

Głównym elementem aparatury, przy określaniu kompatybilności rop, był wysokociśnieniowy układ filtrujący z zamontowanym filtrem szklanym o wielkości porów $0,7 \mu \mathrm{m}$. Modernizacja aparatury polegała na połączeniu komory ciśnieniowej i pojemnika ciśnieniowego umieszczonych w łaźni termostatycznej aparatury PVT z układem filtrującym zanurzonym w oleju grzewczym ultratermostatu, który dodatkowo umożliwił precyzyjne utrzymanie stałej temperatury przepływającej próbki filtrowanej ropy. Jednocześnie w komorach badawczych aparatury PVT utrzymywano próbkę w temperaturze $50^{\circ} \mathrm{C}$ pod ciśnieniem 25 bar przy uruchomionym mieszaniu ropy. Takie podejście wyeliminowało ryzyko wytrącenia i opadania osadu parafinowego w komorach ciśnieniowych, a tym samym popełnienie znaczących błędów przy określaniu jego ilości w warunkach pomiarowych. Następnie przez układ filtrujący przetłaczano badaną próbkę ropy / mieszaniny rop do uzyskania oporów przepływu wynoszących 0,5 bar (różnica ciśnienia przed i za filtrem). Po zakończeniu filtrowania przez układ filtrujący przetłaczano n-heptan celem usunięcia resztek ropy, aby na powierzchni filtra pozostał jedynie odfiltrowany osad. Kolejnym krokiem było osuszenie filtra poprzez przedmuchanie azotem, po czym filtr wraz z obudową ochładzano do temperatury pokojowej. Dopiero tak przygotowany układ filtrujący był rozkręcany, a następnie filtr był wyjmowany i poddawany ważeniu wraz z wychwyconym osadem. 


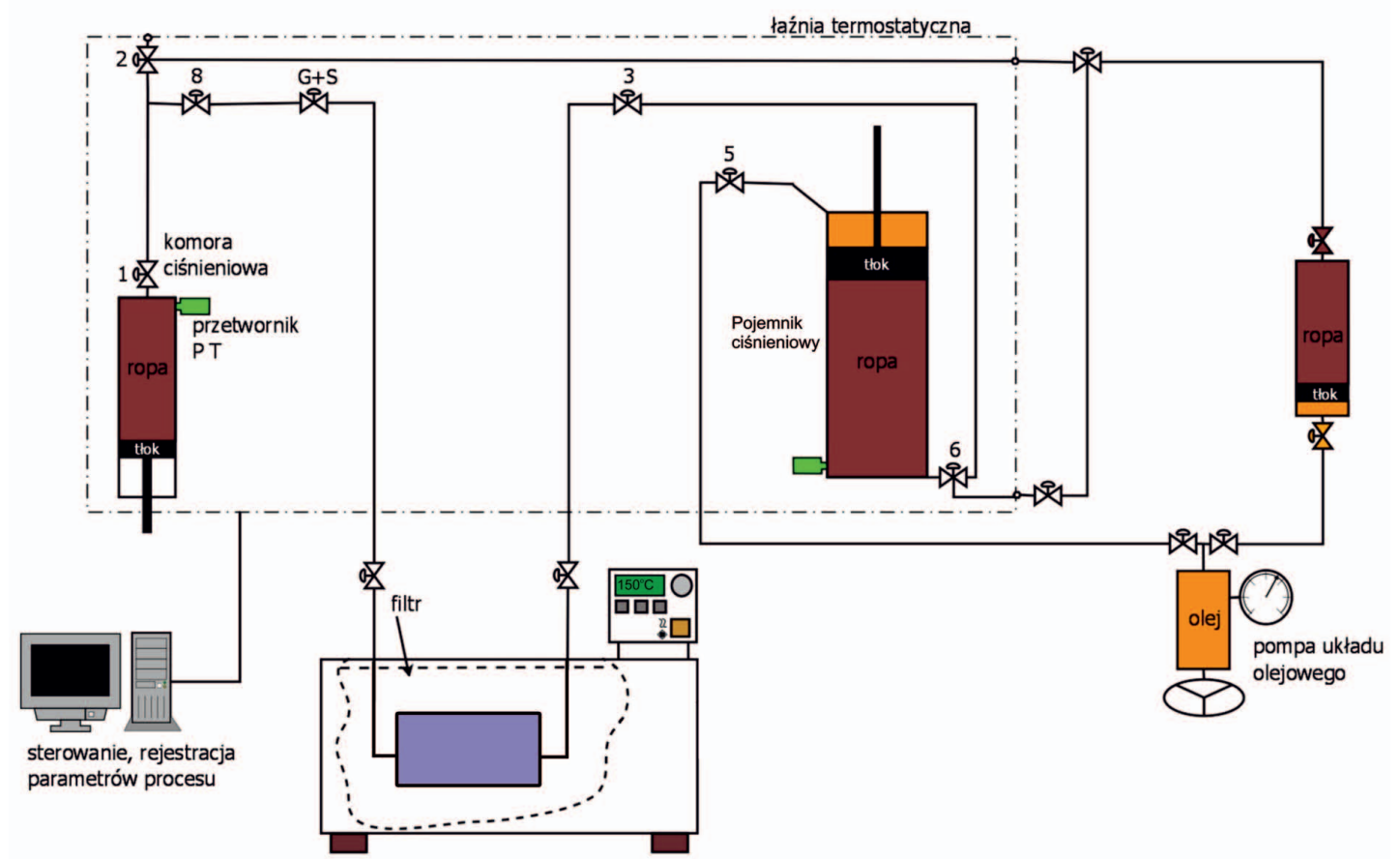

Rys. 3. Schemat aparatury PVT dostosowanej do badań kompatybilności rop metodą filtrowania

Fig. 3. PVT apparatus adapted for testing oil compatibility using the filtration method

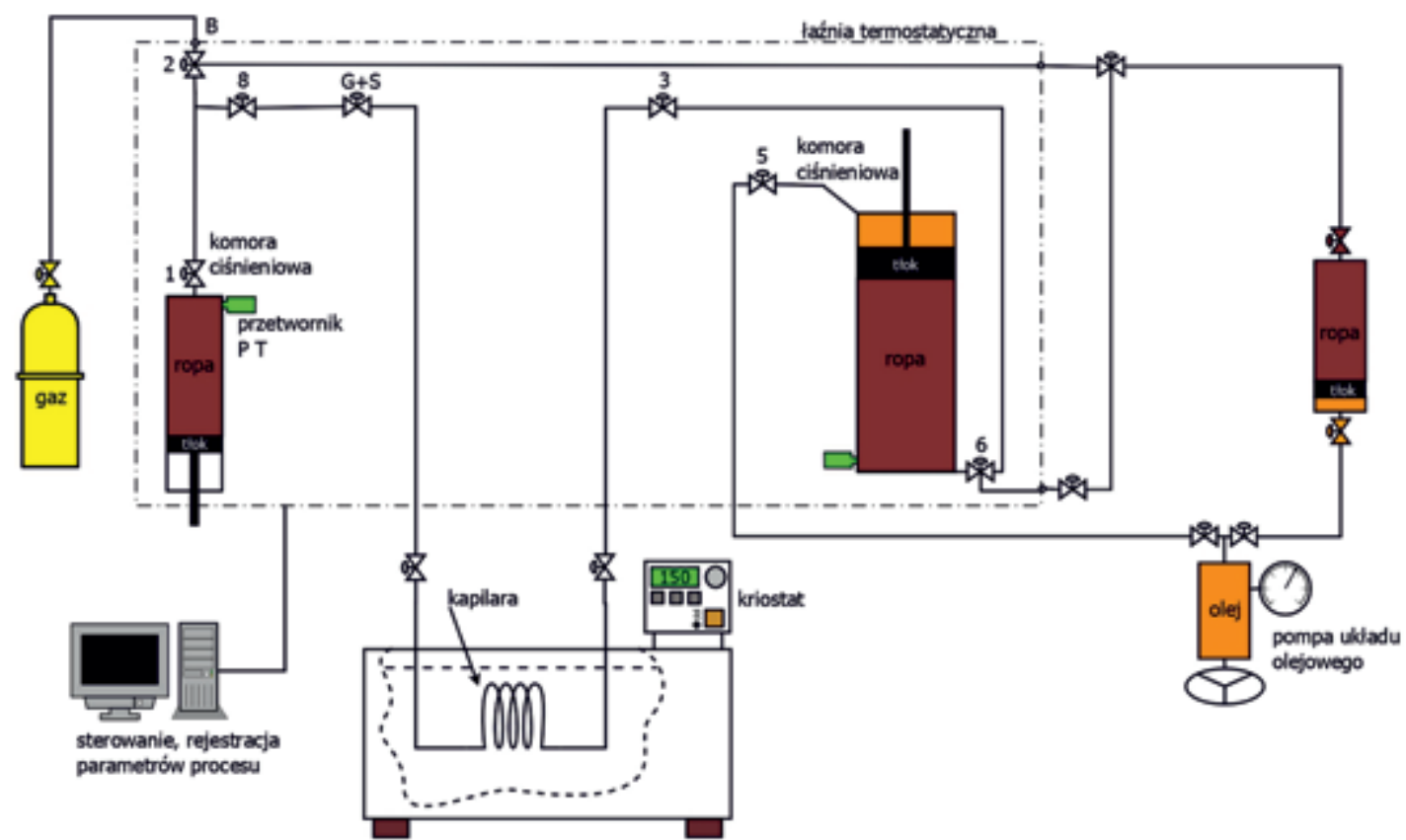

Rys. 4. Aparatura PVT dostosowana do badań kompatybilności rop metodą pompową

Fig. 4. PVT apparatus adapted to testing oil compatibility using the pomp method

Przedstawioną wyżej aparaturę PVT ponownie zmodyfikowano celem wykorzystania do badań kompatybilności rop i ich mieszanin metodą pompową. Do realizacji tych badań zestaw PVT rozbudowano dodatkowo o szereg połączeń wysokociśnieniowych. Zastosowany w poprzedniej metodzie układ filtrujący został zastąpiony przez rurkę kapilarną o średnicy 0,0381 mm i długości $365,76 \mathrm{~cm}$. Głównym celem opracowania nowej metody była możliwość użycia mniejszej objętościowo próbki $\left(200 \mathrm{~cm}^{3}\right)$ oraz możliwość powtórzenia pomiaru, jak również wykorzystania tej samej próbki w innych badaniach.

Przed przystąpieniem do badań kompatybilności rop dla pozyskanych próbek wykonano analizy SARA. W tabeli 1 zestawiono zawartość podstawowych grup substancji tworzących 
ropę naftową, tj. składników węglowodorowych, żywic i asfaltenów. Pozwala to scharakteryzować je następująco (Kluk, 2009):

- węglowodory nasycone (ang. saturate) - mieszanina węglowodorów parafinowych (n-alkanów), izoparafinowych (izoalkanów) oraz naftenowych (cykloalkanów), również zawierających podstawniki alkilowe;

- węglowodory aromatyczne (ang. aromatic) - mieszanina węglowodorów zawierających w cząsteczce jeden lub więcej pierścieni aromatycznych;

- żywice (ang. resin) - silnie polarne związki zawierające w rdzeniu węglowodorowym atomy siarki, tlenu, azotu lub innych pierwiastków;

- asfalteny (ang. asphaltene) - wielkocząsteczkowe związki powstałe na skutek polimeryzacji i polikondensacji żywic.

\section{Wyniki badań}

Tabela 1. Charakterystyka badanych rop naftowych

Table 1. Properties of crude oils tested

\begin{tabular}{|l|c|c|}
\hline \multicolumn{1}{|c|}{ Parametry } & Ropa A & Ropa B \\
\hline \hline Gęstość w $15^{\circ} \mathrm{C}\left[\mathrm{kg} / \mathrm{m}^{3}\right]$ & 870,0 & 891,9 \\
\hline $\begin{array}{l}\text { Zawartość węglowodorów nasyconych [\% } \\
\text { mas.] }\end{array}$ & 25,8 & 44,0 \\
\hline Zawartość asfaltenów [\% mas.] & 2,1 & 1,2 \\
\hline $\begin{array}{l}\text { Zawartość węglowodorów aromatycznych } \\
\text { [\% mas.] }\end{array}$ & 26,2 & 24,1 \\
\hline Zawartość żywic [\% mas.] & 14,6 & 10,8 \\
\hline
\end{tabular}

Na rysunkach 6-9 zebrano wyniki pomiaru kompatybilności dwóch rop A i B dla różnych prędkości tłoczenia. Wyniki pogrupowano w 4 serie badawcze, po jednej dla każdej z prędkości tłoczenia. Analizując pomiary wykonane metodą pompową, nie udało się wyznaczyć udziałów procentowych rop w mieszaninie, dla których nie wykazywałyby kompatybilności. W przypadku braku kompatybilności badanych mieszanin rop wartości oporów przepływu przekroczyłyby czerwoną linię łączącą zmierzone opory przepływu dla czystych próbek rop.

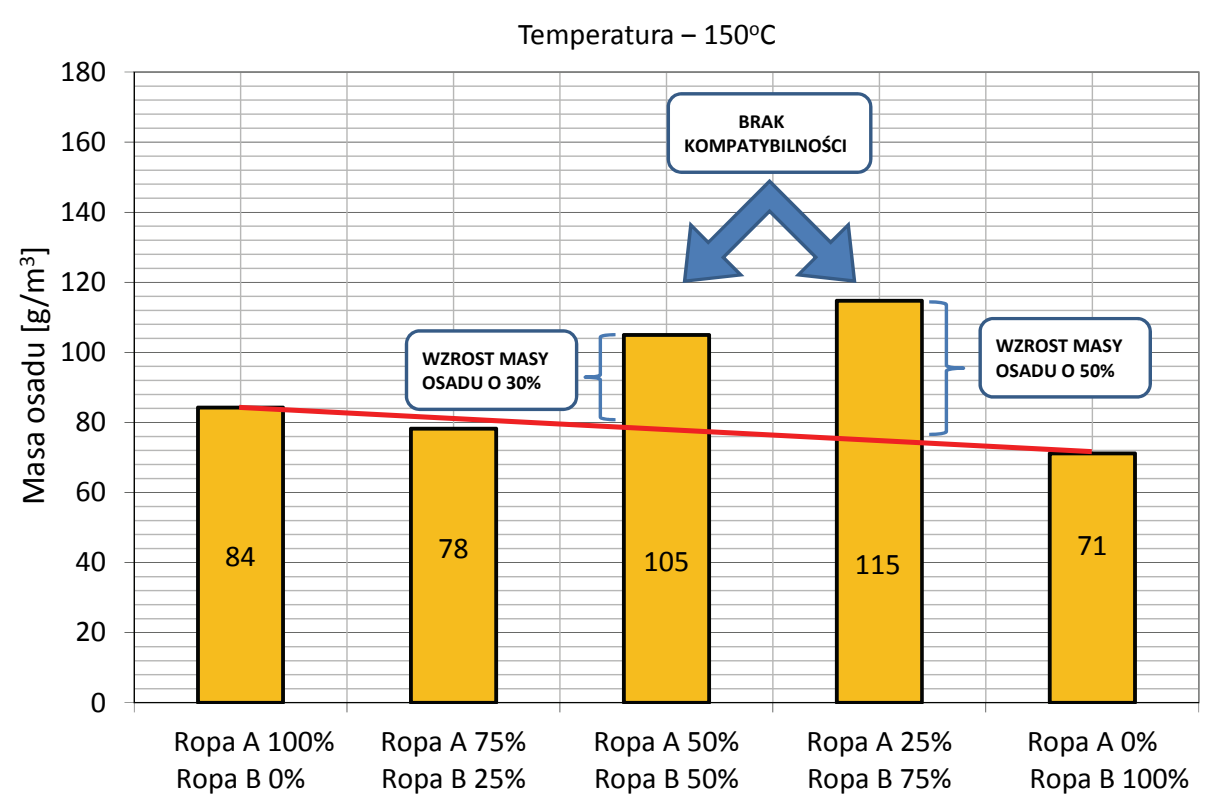

Rys. 5. Wpływ zmian zawartości ropy B w ropie A na ilość masy osadu wyrażoną $\mathrm{w} / \mathrm{m}^{3}$

Fig. 5. Impact of changes in B oil samples content in A oil samples on the amount of sludge mass expressed in $\mathrm{g} / \mathrm{m}^{3}$ 


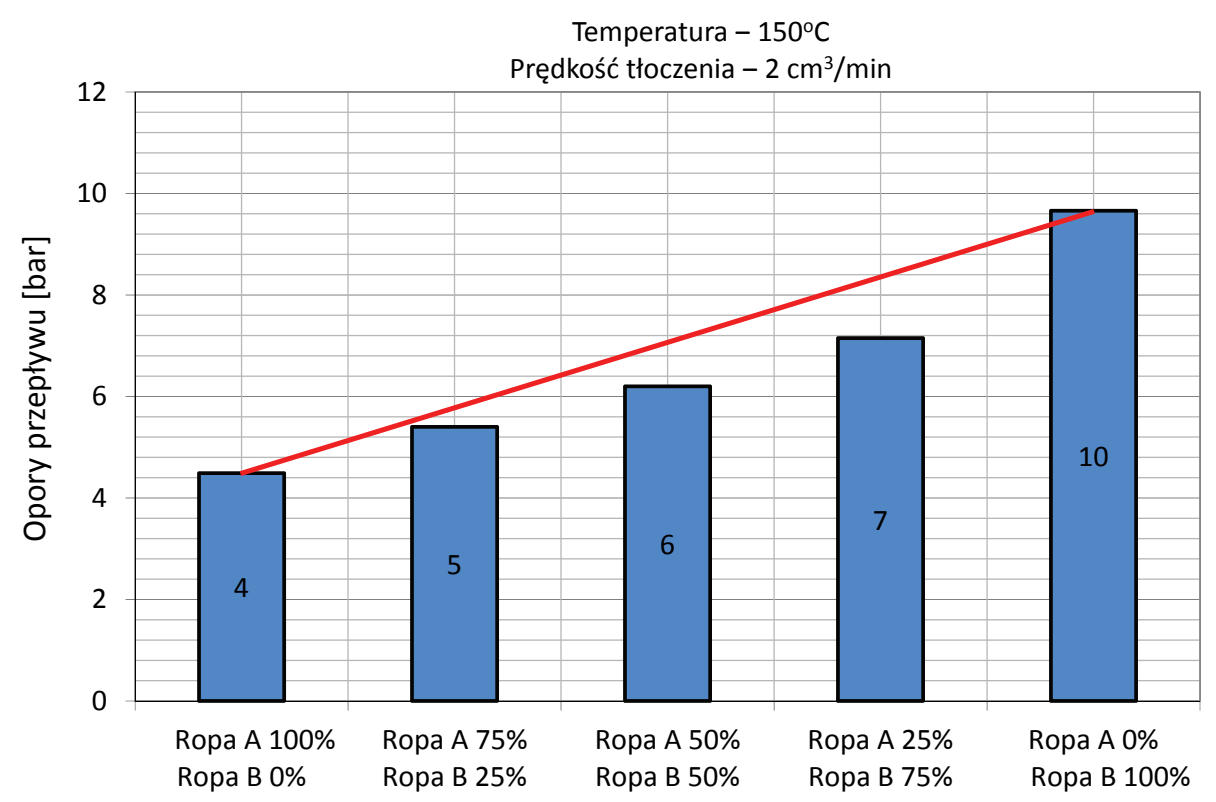

Temperatura $-150^{\circ} \mathrm{C}$

Prędkość tłoczenia $-5 \mathrm{~cm}^{3} / \mathrm{min}$

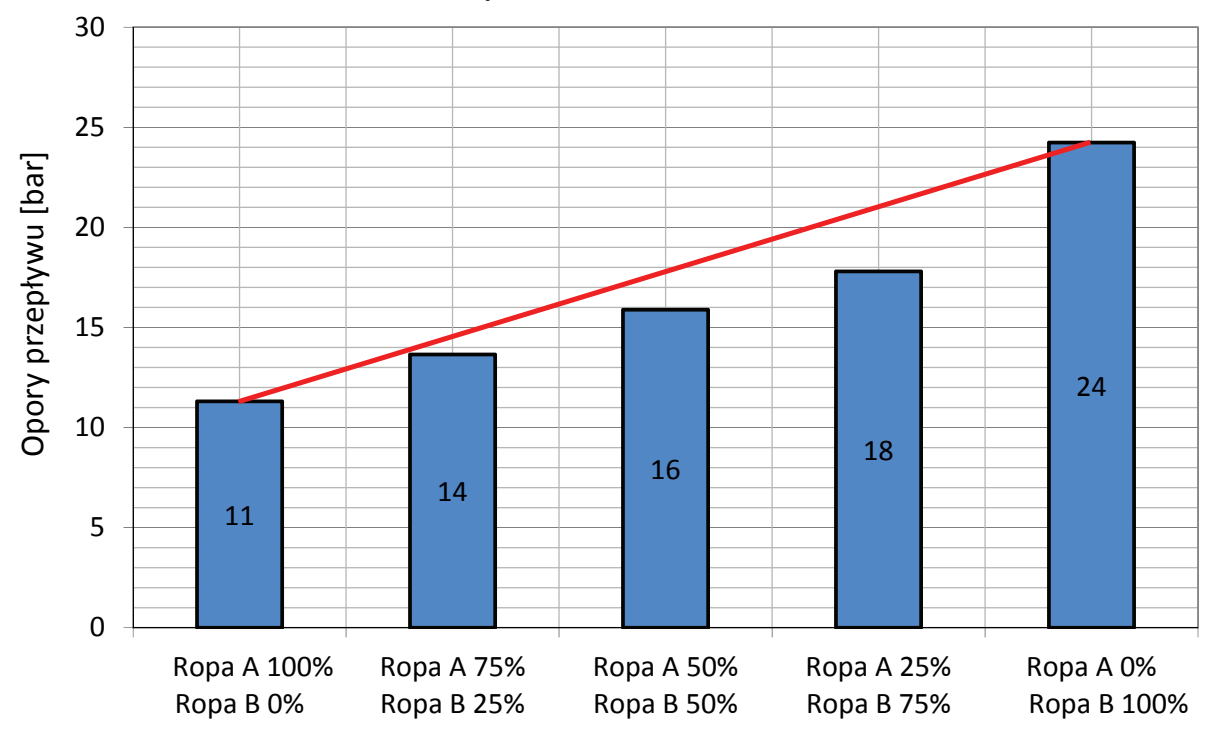

Temperatura $-150^{\circ} \mathrm{C}$

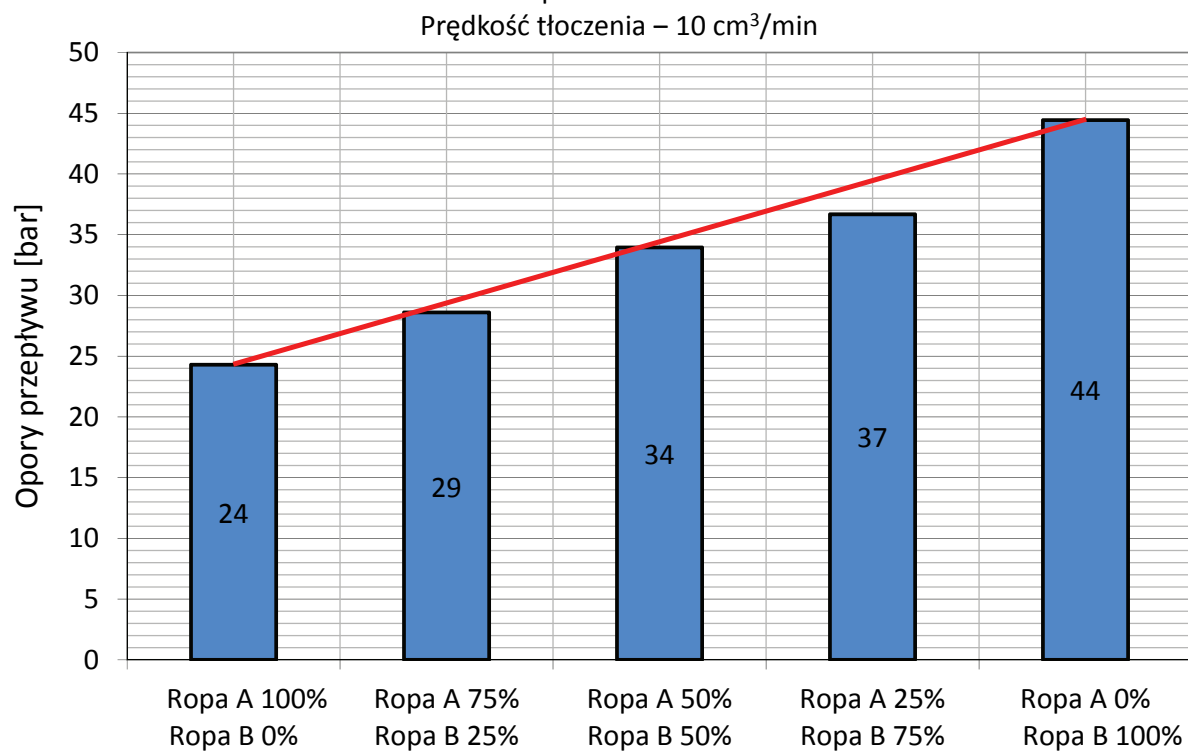

Rys. 6. Wpływ zmian zawartości ropy B w ropie A na opory przepływu dla prędkości tłoczenia $2 \mathrm{~cm}^{3} / \mathrm{min}$

Fig. 6. Impact of changes in B oil samples content in A oil samples on the amount of flow resistance for flow rate of $2 \mathrm{~cm}^{3} / \mathrm{min}$

Rys. 7. Wpływ zmian zawartości ropy B w ropie A na opory przepływu dla prędkości tłoczenia $5 \mathrm{~cm}^{3} / \mathrm{min}$

Fig. 7. Impact of changes in B oil samples content in A oil samples on the amount of flow resistance for flow rate of $5 \mathrm{~cm}^{3} / \mathrm{min}$

Rys. 8. Wpływ zmian zawartości ropy B w ropie A na opory przepływu dla prędkości tłoczenia $10 \mathrm{~cm}^{3} / \mathrm{min}$

Fig. 8. Impact of changes in B oil samples content in A oil samples on the amount of flow resistance for flow rate of $10 \mathrm{~cm}^{3} / \mathrm{min}$ 


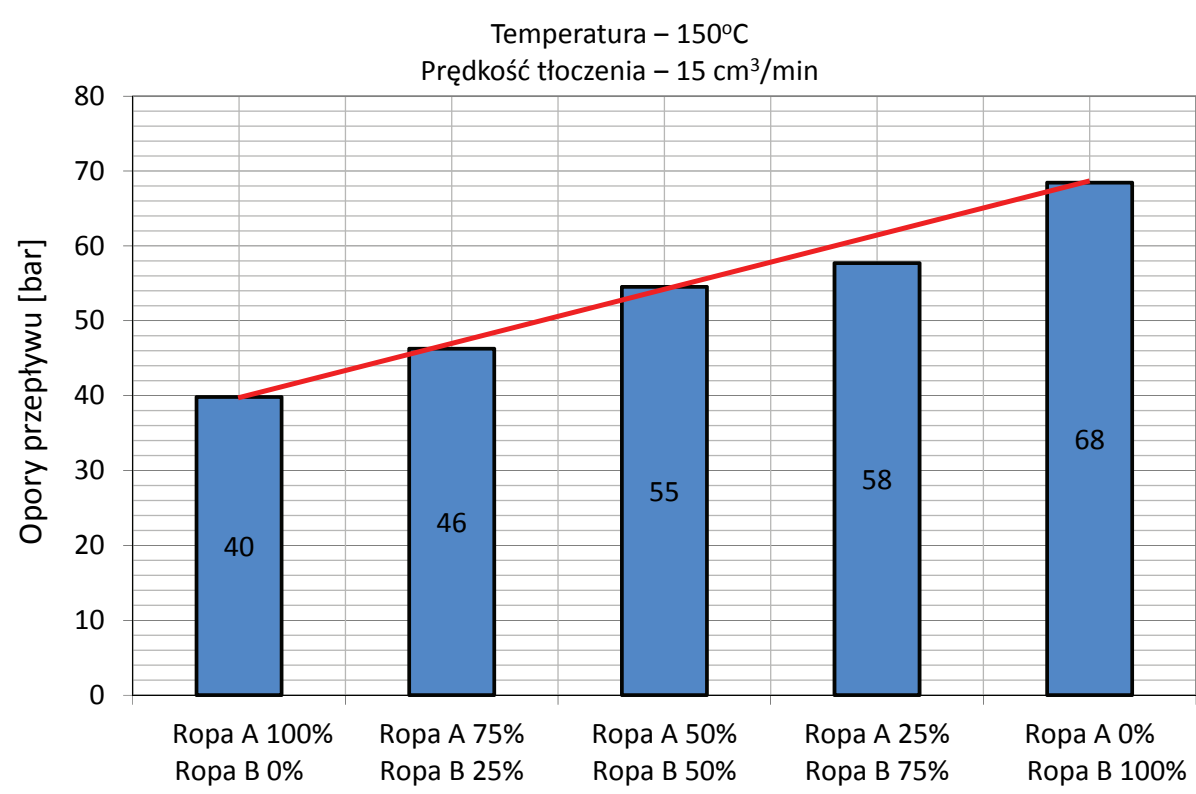

Rys. 9. Wpływ zmian zawartości ropy B $\mathrm{W}$ ropie A na opory przepływu dla prędkości tłoczenia $15 \mathrm{~cm}^{3} / \mathrm{min}$

Fig. 9. Impact of changes in B oil samples content in A oil samples on the amount of flow resistance for flow rate of $15 \mathrm{~cm}^{3} / \mathrm{min}$

\section{Podsumowanie}

Głównym celem pracy była ocena skuteczności nowo opracowywanej metodyki badań kompatybilności rop - do tego celu wykorzystano dwie ropy pochodzące $\mathrm{z}$ różnych kierunków dostaw. Najpierw wykonano szereg testów kompatybilności rop nowo opracowywaną metodą pompową. W następnej kolejności przeprowadzono pomiar kompatybilności wcześniej opracowaną metodą filtrowania, pozwalającą na wyznaczenie zawartości osadu w czystych próbkach rop, a następnie wykonano pomiar ilości osadu dla mieszanin ropnych w trzech różnych stężeniach objętościowych w krokach co $25 \%$.

Na podstawie przeprowadzonych pomiarów metodą filtrowania udało się wykazać brak kompatybilności próbki ropy A z B, lecz nie dla każdej mieszaniny. Okazuje się, że w temperaturze pomiaru ropy A i B są kompatybilne pod warunkiem, że udział ropy B w mieszaninie z ropą A nie przekroczy $25 \%$. Brak kompatybilności wykazano dla dwóch mieszanin, w których zawartość ropy B stanowiła minimum $50 \%$ i więcej całkowitej mieszaniny. Brak kompatybilności objawiał się znaczącym przyrostem ilości wychwyconego osadu w trakcie pomiaru, dochodzącym do 50\% (rys. 5).

Przeprowadzając pomiary metodą pompową, nie udało się niestety wyznaczyć udziałów procentowych rop w mieszaninie, dla których ropy nie wykazywałyby kompatybilności. Zastosowano cztery różne prędkości tłoczenia, które konsekwentnie powodowały otrzymywanie coraz większej różnicy ciśnień w trakcie przepływu. Takie podejście minimalizowało wpływ dokładności rejestrowania ciśnienia różnicowego. $\mathrm{W}$ trakcie pomiarów dla różnych prędkości tłoczenia nie wykazano wzrostu oporów przepływu spowodowanego pojawieniem się dodatkowych ilości osadów stałych. Najprawdopodobniej ich przyrost w całkowitym strumieniu jest na tyle mały, że nie mógł spowodować wzrost ciśnienia różnicowego i doprowadzić do przekroczenia umownej „,zerwonej linii” wyznaczonej na każdym z rysunków (rys. 6-9).

Brak dostępnej na rynku specjalistycznej aparatury umożliwiającej wykonanie szybkich pomiarów kompatybilności rop z uwzględnieniem parametrów ciśnienia i temperatury wymusił przystosowanie posiadanej aparatury PVT do wyżej opisanych badań. Niestety Zakład Badania Złóż Ropy i Gazu nie może dopisać do swojej oferty badawczej kolejnego sposobu badań, który cechowałby się dużą powtarzalnością i dokładnością.

Artykuł powstał na podstawie pracy statutowej pt. Ocena kompatybilności rop naftowych metoda pompowa i filtracyjna - praca INiG - PIB na zlecenie MNiSW; nr zlecenia: 0065/KB/2020, nr archiwalny: DK-4100-0053/2020.

\section{Literatura}

Asomaning S., Watkinson A.P., 2000. Petroleum stability and heteroatom species effects in fouling of heat exchangers by asphaltenes. Heat Transfer Engineering, 21(3): 10-16. DOI: $10.1080 / 014576300270852$.

Goual L., Firoozabadi A., 2002. Measuring asphaltenes and resins, and dipole moment in petroleum fluids. AIChE Journal, 48(11): 2646-2663. DOI: 10.1002/aic.690481124.

Guzmán R., Ancheyta J., Trejo F., Rodríguez S., 2017. Methods for determining asphaltene stability in crude oils. Fuel, 188: 530-543. DOI: $10.1016 /$ j.fuel.2016.10.012.

Kluk D., 2009. Oznaczanie składu ropy naftowej z wykorzystaniem aplikacji SARA. Nafta-Gaz, 3: 255-261.

Krasodomski W., Altkorn B., Duda A., Szuflita S., Krasodomski M., 2020. Problemy kompatybilności rop naftowych. Nafta-Gaz, 5: 332-339. DOI: 10.18668/NG.2020.05.06. 
Lubaś J., Biały E., Warnecki M., 2012. Asfalteny w problematyce wydobycia ropy naftowej. Prace Naukowe Instytutu Nafty i Gazu, 179: 1-121.

Painter P., Veytsman B., Youtcheff J., 2015. Guide to asphaltene solubility. Energy and Fuels, 29(5): 2951-2961. DOI: 10.1021/ ef502918t.

Pfeiffer J.P., Saal R.N.J., 1940. Asphaltic bitumen as colloid system. Journal of Physical Chemistry, 44(2), 139-149. DOI: 10.1021/ j150398a001.

Rogel E., Carbognani L., 2003. Density estimation of asphaltenes using molecular dynamics simulations. Energy and Fuels, 17(2): 378-386. DOI: 10.1021/ef020200r.

Sepúlveda J.A., Bonilla J.P., Medina Y., 2010. Prediction for Asphaltenes Using SARA Analysis for Pure Petroleum. Revista Ingeniería, 7, 103-110.

Stankiewicz A., Flannery M.D., Fuex N.A., Broze J.G., Coach J.L., Dubey S.T., Leitko A.D., Nimmons J.F., Iyer S.D., Ratulowski J., 2002. Prediction of Asphaltene Deposition Risk in E P Operations. Proceedings of the International Conference on Petroleum Phase Behavior and Fouling, American Institute of Chemical Engineers: 410-416. ISBN: 0816997748.

Wang J., Buckley J.S., 2003. Asphaltene Stability in Crude Oil and Aromatic Solvents - The Influence of Oil Composition. Energy and Fuels, 17(6): 1445-1451. DOI: 10.1021/ef030030y.

Warnecki M., 2011. Doskonalenie techniki badań warunków flokulacji asfaltenów metodą prześwietlania ropy strumieniem światła podczerwonego. Nafta-Gaz, 7: 454-462.

Wiehe I.A., 2008. Process chemistry of petroleum macromolecules. CRC Press.

Wiehe I., Kennedy R., 2000. The Oil Compatibility Model and Crude Oil Incompatibility. Energy \& Fuels, 14: 56-59.

\section{Akty prawne i dokumenty normatywne}

ASTM D5186-19 Standard Test Method for Determination of the Aromatic Content and Polynuclear Aromatic Content of Diesel Fuels By Supercritical Fluid Chromatography.

ASTM D4740-19 Standard Test Method for Cleanliness and Compatibility of Residual Fuels by Spot Test.
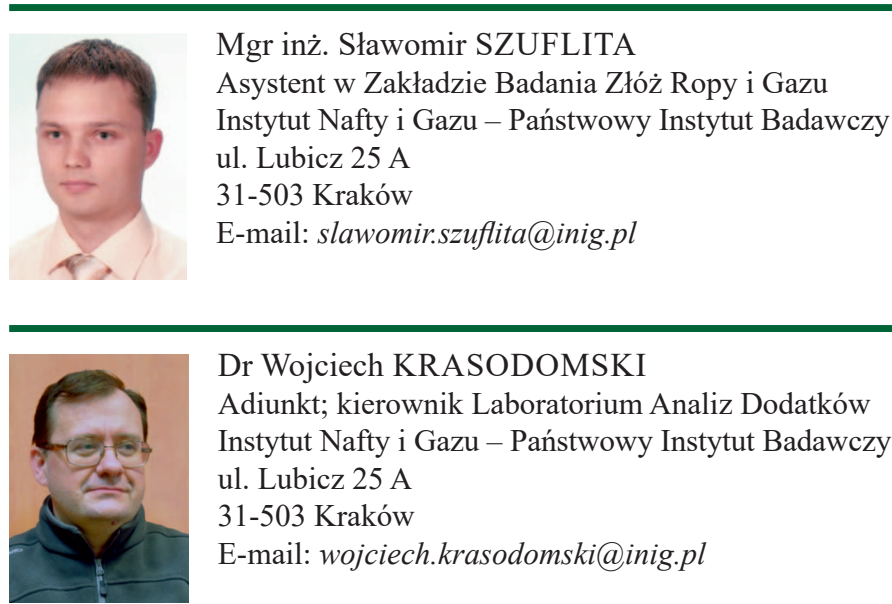

Dr Wojciech KRASODOMSKI

Adiunkt; kierownik Laboratorium Analiz Dodatków Instytut Nafty i Gazu - Państwowy Instytut Badawczy ul. Lubicz $25 \mathrm{~A}$

31-503 Kraków

E-mail: wojciech.krasodomski@inig.pl

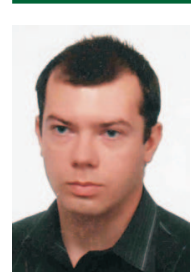

Mgr inż. Jerzy KUŚNIERCZYK

Specjalista badawczo-techniczny w Zakładzie

Badania Złóż Ropy i Gazu

Instytut Nafty i Gazu - Państwowy Instytut Badawczy ul. Lubicz 25 A

31-503 Kraków

E-mail: jerzy.kusnierczyk@inig.pl

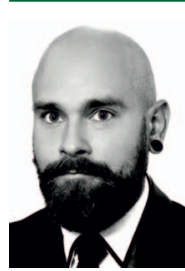

Dr inż. Mirosław WOJNICKI

Asystent w Zakładzie Badania Złóż Ropy i Gazu Instytut Nafty i Gazu - Państwowy Instytut Badawczy ul. Lubicz 25 A

31-503 Kraków

E-mail: miroslaw.wojnicki@inig.pl

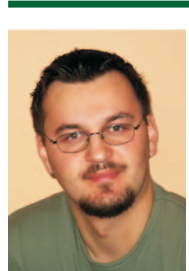

Dr inż. Marcin WARNECKI

Kierownik Zakładu Badania Złóż Ropy i Gazu Instytut Nafty i Gazu - Państwowy Instytut Badawczy ul. Lubicz $25 \mathrm{~A}$

31-503 Kraków

E-mail: marcin.warnecki@inig.pl 